\title{
In Memory of Bernard Stiegler (1 April 1952-5 August 2020)
}

\author{
Pieter Lemmens ${ }^{1}$
}

Published online: 30 March 2021

(c) The Author(s), under exclusive licence to Springer Nature B.V. part of Springer Nature 2021

When a friend mailed me in the evening of the 6th of August this year (2020) that he got informed via Facebook that Bernard Stiegler had died that day, I could not believe it at first. As a deliberate non-user of Facebook or any other electronic grapevine that goes for 'social media' nowadays, I immediately went online to check for confirmation on some website but couldn't find any yet. Two hours later, though, I received another e-mail from a British colleague closely related to Bernard that conveyed the same sad news. I was flabbergasted, really at a loss. How could it be that this great philosopher, this exceptionally brilliant and productive thinker, this incredibly prolific author and tireless intellectual activist who taught and inspired so many thinkers young and old all over the world, and who was truly at the height of his career and still full of ambitions, had suddenly passed away, at age 68, way too early? All the projects that he was still involved in, all the books and further volumes that were still to be written or completed (and how many of these were announced in the footnotes in his books?), all the promising horizons that were radiating from his texts and from his amiable and admirable person? He was the originating and inexhaustible driving force of so many things! His voice, his sharp intelligence, his warmth, his humility but also his prophetic severity, his shining example of a genuine philosophical vita activa et contemplativa. All this will be tremendously missed by all who have known and cooperated with him, and his passing represents a great loss for the philosophical community. With the death of Bernard, maybe the last genuine maître penseur of our times, philosophy has lost one of its true giants.

A couple of weeks before his passing Bernard mailed me that despite being very busy as usual, he would try to write the final reply to his respondents. And I fully trusted he would manage, as had always been the case in the past. Bernard never let me down. Yet this time it was different of course, and that is why you are now reading my in memoriam instead of his thoughts on the comments of Vincent Blok and Alexander Wilson on his article, which would have been much more exciting no doubt but which will be lacking forever unfortunately. And I did't feel authorized let alone capable to respond in his name.

I have never been very close to Bernard but I have met him in person a couple of times and of all these encounters I retain fond memories, which I will try to recall below. But before meeting him in person for the first time ten years ago, I was struck by his work, which blew me away and truly allowed me for the first time to understand Martin Heidegger in a way that could really satisfy me. I first encountered that work in late 2005,

Pieter Lemmens

p.lemmens@science.ru.nl

1 Radboud University, Institute for Science in Society, Nijmegen, The Netherlands 
when I more or less accidentally (an important notion for Bernard, who 'became a philosopher by accident') stumbled upon the English translation of the first volume of Technics and Time in the library of our philosophy faculty at Radboud University in Nijmegen. I was at the time writing my dissertation on the implications of the biotechnology revolution for the human condition. Yet, as someone initially trained as an (evolutionary) biologist with a special interest in human evolution but having become hopelessly fascinated with Heidegger's phenomenology and existential ontology during my philosophy study, I was particularly puzzled by the question of how something like Dasein or the human as an existing being could have ever come into being through a biological process of evolution.

At the time I had already learned from Peter Sloterdijk's notorious 1999 lecture 'Rules for the Human Park' and later from the chapter 'The Domestication of Being', both to be found in his 2001 book on Heidegger, Not Saved: Essays after Heidegger (Sloterdijk 2017) that the human in terms of what Heidegger called Dasein could and should be thought of as being the result not of a process of biological evolution but of technological evolution, i.e., of technogenesis as Sloterdijk put it in that book, a term that was also used by Stiegler as I later found out while reading Technics and Time 1 (Stiegler 1998). At first I found that book very hard to penetrate, due no doubt in part to the difficulty of the subject but also to Stiegler's writing style, which is not the easiest as many of us will immediately admit, but most probably also due to the translation, which was not the best one and in which I discovered not a few errors after having read the original French version later on and compared some all-too-enigmatic passages. Stiegler in French is definitely clearer and less challenging than in English, and French is in fact a much more analytic and 'rationalist' language than English as I began to recognize more and more. But after putting more effort in the book and re-reading it a couple of times in both languages, I started to grasp its profound meaning, the enormity of the project that it aimed to initiate, and I began to appreciate Technics and Time as the landmark treatise that it is, on a par with books such as The Phenomenology of Spirit, Logical Investigations and of course Being and Time itself. Alas, Technics and Time will now remain unvollendet forever, although at least parts of the fourth and maybe also of the fifth, sixth and seventh volumes (as announced in the preface to the 2018 republication of the first three volumes with Fayard) will still appear in some form, since Bernard was constantly in the process of completing them.

After studying Technics and Time 1 for a couple of months and becoming ever more entranced by it (under the spell of its pharmacology), I realized that this would become a very important event in my life and I decided that I had to read everything that its author had written. And that is what I did, ordering all the original French titles that I could lay my hands on and voraciously taking them in. And this happened almost as in a rush, indeed an exuberant intoxication. I was utterly hooked. It was 2006 and I had just moved into another house with my family. That summer was exceptionally hot and I remember myself sitting on the couch in that still rather empty living room in which a whole swarm of different insects had gathered on the freshly painted white ceiling each night, in the cooling breeze of the ventilator, and reading night after night until very late the two volumes of $D e$ la misère symbolique, the three volumes of Mécréance et discrédit, which were just out then, and all the other available titles as well. Never after my encounter with Heidegger had I been so struck by a philosopher. Bernard became an important voice in my dissertation and ever since have I been closely following his work and writing about it. In 2007 I watched the mesmerizing documentary The Ister, by Daniel Ross and David Barison, in which Bernard featured prominently.

I first met Bernard in person on the 14th of September in 2010, when I visited him for an interview (Lemmens 2011) in his office at the Institut de Recherche et d'Innovation 
(IRI) in the nondescript white appartment block opposite of the colourful Centre Pompidou in the bustling centre of Paris. I was very happy at the time that he had allowed me to interview him in the first place and that he was also willing to do that in English, as I was aware that French would be much more convenient for him. This was the first time that I regretted my poor French-speaking capabilities. Yet I have never managed to bring them up to a level good enough to have a really in-depth conversation with him and every time I met him since I have felt a bit of shame for still being unable to speak with him in his native language. Anyway, as I remember, he had his residence at the very top floor of the building, on a kind of loft where he sat at a huge desk overseeing the IRI-people working below. What struck me immediately when we started to talk was his enormous friendliness and warmth, his approachability and the complete lack of arrogance or 'attitude' that so many lesser minds in the academic world so frequently exhibit.

I had come in particular to ask him about his thoughts on open source and commonsbased practices of innovation and production in the digital and bio-economy, the subject of my post-doc project at the time, from his perspective of the 'economy of contribution'. Soon enough though we were engaged in a discussion on the more general aspects of his views on technology as well as on the current tendency of capitalist-controlled digital innovation to produce increasing stupidity, irrationality, proletarianization, addiction and what he called symbolic misery. When talking about addiction he confessed that he had been an addict himself once and he referred to Naked Lunch by William Burroughs, a novel about heroine addiction which, he argued, conveyed like nothing else the true nature of addiction: the impossibility to stop (using) despite desperately hating it and wanting to stop (using). 'Capitalism is now confronted with this problem', he argued. The truth of this insight has become ever more apparent since then of course. Only Covid-19 has managed to engender at least a temporary and partial halt to the ruthless capitalist juggernaut, but there is no sign yet of anything even remotely resembling what Heidegger called Besinnung. Obviously Bernard first of all had consumerist addiction in mind, probably not knowing already at the time, as neither I did, about the extent of state-sponsored opioid addiction in the USA, which has been escalating in the last decade. He did relate, though, that over $15 \%$ of the American youth used drugs such as Ritalin and Prozac, and without doubt this has also been increasing, the obvious reason being that 'this system does not produce pleasure anymore', as he asserted. Bernard alluded to Burroughs in his books only on a few occasions as I recall, but I have the feeling that the writings, both literary and 'theoretical', of this arch-junkie and greatest intellect of the beats had a significant influence on his philosophical project. At least I have always sensed a more than coincidental affinity with Burroughs' views on language as a virus and his scathing critique of capitalist society in general and American capitalism — or 'the American nightmare' - in particular.

I began corresponding more often with Bernard in 2013 when I translated his volume of interviews with Élie During, Philosopher par accident (Stiegler 2004, English translation: Stiegler 2017) in Dutch (Stiegler 2014). When the book came out in 2014 I first invited him to the Netherlands for a lecture at our university, which he gave in a lecture hall fully packed with students, who apparently had a hard time following his train of thought, which largely flew over their heads due not only to its intrinsic complexity but also because of his now already legendary, in Nijmegen that is, 'Fringlish' (French-English). Since that first visit, I have invited him three more times to Nijmegen for lectures or participation in seminars. In August of 2014 I took part for the first time in the Pharmakon summer school, which he organized every year since 2011 together with the Ars Industrialis association in Épineuil in the middle of France, on the estate of his home residence. There are two things that I remember especially from these week-long events in the sunny French countryside, 
which were attended not only by professional philosophers from all over the world (some of whom were camping on the grass near his house) but also by local citizens. One is the enormous energy and spirit with which Bernard animated the discussions as well as the extensive, thoughtful, indeed carefully crafted comments that he always offered to each speaker at the end of the day's long sessions. The other is the friendly and immensely joyful atmosphere during the long evenings when everybody gathered around the large wooden tables in the garden around the house to share a most excellent diner, drink wine, engage in philosophical conversations and get to know each other more intimately. I sometimes felt as if I had landed in the garden of Epicurus.

In June 2016 I organized a meeting between Peter Sloterdijk and Bernard in collaboration with Yuk Hui and the Nootechnics collective on the topic of the Anthropocene. Besides a two-day academic seminar with a choice of international speakers, we also arranged a big public event at which Bernard and Sloterdijk crossed swords on the Anthropocene. This event was held in the great concert hall in the city center and completely sold out with over 1500 people attending. A great success publicity-wise, yet the utimate 'harvest' proved rather poor, as Sloterdijk largely refused to respond and instead chose to play the clown, thereby entertaing the audience, which starkly contrasted with Bernard's enthousiastic but also schoolmasterly attempts to teach it about the gravity of our predicament in the Anthropocene. Something similar happened in the seminar. While Bernard was very eager and willing to enter into a serious debate with the colossus from Karlsruhe all the time, constantly addressing and provoking him, the latter persisted in his typical monologues and only at the very end managed to give at least the impression of being engaged in a dialogue. Bernard had also prepared notes for the event and had dealt with Sloterdijk's theory of 'disinhibition' from the 2005 treatise In the World Interior of Capital (Sloterdijk 2013) in his then just published book Dans la disruption. Comment ne pas devenir fou? (Stiegler 2016) a copy of which we also sent to Sloterdijk, accompanied with a personal letter. Yet no response has ever been heard and there is no sign at all that Sloterdijk has ever made any effort to respond. All in all I think it was largely a failed encounter, unfortunately. I still remember Bernard telling me back in 2010 in Paris that he considered Sloterdijk to be a sophist, 'a brilliant sophist, very brilliant, but a sophist nevertheless'.

In January 2018 I invited Bernard again to Nijmegen for an encounter with the doyen of American philosophy of technology, the postphenomenologist Don Ihde, about the theme of the special issue you're now reading: the future of philosophy of technology in the age of the Anthropocene. Although coming from pretty similar backgrounds philosophically and having both 'technologized' phenomenology each in their own particular ways, Ihde and Bernard had quite different opinions on how to think and approach technology in the current conjuncture of global ecological crisis and ubiquitous digitalization, based on widely diverging diagnoses of our predicament (which can be gathered fom their respective contributions in this issue). There was a lively and friendly debate though and thanks also to the presentations of all the other authors contributing to this issue it was a great success, as our readers will hopefully be able to confirm. And again it was remarkable during this seminar to perceive the contrast between Bernard's combative style and esprit de sérieux and the more relativizing, pragmatist, relaxed attitude in debating characteristic of Ihde, sprinkled with humorous and ironic digressions. When Bernard spoke though, with a solemn voice, the audience was particularly silent and got to listen carefully to an entirely new and utterly original interpretation of Heidegger's notions of Gestell, Ereignis and die Kehre, which can now be read in his contribution included in this issue. So is Ihde's fierce critique of anything transcendental in philosophy of technology and his uncompromising defense of the empirical turn. 
In my undoubtedly simplistic understanding, Bernard in a way did to Heidegger what Marx did to Hegel: turning his thought around as it were and putting it on its feet, i.e., by offering a materialist re-interpretation of Heidegger's still transcendentalist or even idealist understanding of human existence and of what the latter called the question of Being. What he (Bernard) showed in great detail, and that is to say in meticulous phenomenological meta-analyses of Heidegger's existential ontology, is that the temporal and historial dynamic of Dasein's mode of being as being-in-the-world is fundamentally, and that is to say originally, constituted and conditioned by technology in the ontic sense. Existential time is constituted by technics and the human condition as 'originally being in default' is a technical condition through and through. This is Bernard's great insight, which he has elaborated ever since, applying it to all dimensions of human existence (from philosophy, politics, ethics, history and economics to science, anthropology, education, psychoanalysis and the arts) and taking it as the key to a deconstructive reading of the Western philosophical tradition as a whole from Plato to Heidegger and his own teacher Derrida, whose most original reader he had no doubt become. Like Sloterdijk, but in a much more profound and incisive way, he combined Heideggerian existential ontology and the thinking of Being with (paleo)anthropology (in his case that of André Leroi-Gourhan) to show how the human's openness to Being and understanding of beings has emerged and evolved through a process of technical exteriorization (and biological interiorization) and how the history of truth can be understood as resulting from successive adoptions of the ongoing transformations of technical systems as they periodically_and today in the 'age of disruption' permanently-re-condition the human condition.

While the first volume of Technics and Time laid most of the theoretical groundwork for his project by demonstrating why our time and most decisively our future should be thought of as conditioned by the specifics of its technical prostheses, the second volume (Stiegler 2009a), which addressed the current 'disorientation', showed how this conditioning had taken place throughout the history of the West and why the current technical prosthesis, i.e., digital technology in the context of global capitalism, obstructs proper adoption and instead produces adaptation. The third volume (Stiegler 2011) began to explicitly put this question into a politico-economic context and initiated the project of renewing the critique of political economy for the twenty-first century - as a critique of libidinal economy. It also started Bernard's more active engagement with what he called technopolitics and noopolitics, which led in 2005 to the establishment of Ars Industrialis, an international association for the industrial politics of the mind. In later works, from the 2003 essay 'To Love, to Love Me, to Love Us' (in: Stiegler 2009b) onwards, he always combined a philosophical diagnosis and prognosis with political and politico-economic proposals for a therapy, all the while elaborating and refining his massive and powerful conceptual apparatus. This culminated eventually in his organology and pharmacology of technology, which he began to theorize in terms of entropy and negentropy since the General Organology conference in 2014 in Canterbury (in: Stiegler 2018). Since 2016 he put his ideas on deproletarianization and contributory economics in practice through the Plaine Commune project in the Parisian suburb of Seine-Saint Denis, in cooperation with the municipality and French technology companies Dassault and Orange.

Bernard always insisted that he was not a philosopher of technology in the usual sense of the word, i.e., someone who thinks about technology as a specific object domain. For Bernard technology, being the very condition of thinking and indeed of existing as such, was nothing less than the object of philosophy par excellence, i.e., the original yet originally repressed (in the history of metaphysics) question of philosophy. He thus asked the question of philosophy in the same way that Heidegger asked the question of Being and 
he claimed that more original than the forgetting of Being was the forgetting of technology. And any question of Being by Dasein presupposes its prior being put into question by technology. Philosophy itself, he argued, originated in ancient Greece from what could be called a pharmacological 'trauma', i.e., from the disruptive introduction of alphabetic writing technology in oral Greek culture and its ambiguous effects on the Greek psyche and society, soon to become the polis. Philosophy started off as an attempt to adopt the pharmakon of writing, that powerful magic potion interfering with the mythic mindset, as a medicine for the mind, and understood itself as a 'therapy for the soul'. This is also why for Bernard the first question of philosophy is not that of Being but of teaching, of teaching the practice of philosophizing as it is based from the outset on the pharmakon (here of writing), although precisely this has been consistently repressed from Plato onwards. A similar repression largely persists in today's institutions of learning with respect to the 'digital disruption', to which capitalism has responded much more profitably (although self-destructive in the longer run as we are now in the process of experiencing) - to the detriment of the life of the mind. It is in this context that Bernard called for a new 'battle of intelligence' to fight the current 'denoetization' and work to usher in a noetic renaissance for the digital and ecological age, which is so desperately needed in our dire time of total nihilism, posttruth, systemic stupidity and generalized corruption of the financial and political sphere.

Bernard was the eminent thinker of crisis and catastrophe and for him the time of crisis was the time of philosophy. Every great philosophy is at heart a response to a situation of profound crisis, confronting it at its height, be it that of Plato, Augustine, Descartes, Kant, Hegel, Marx, Nietzsche, Husserl, Heidegger or Lyotard. And every crisis demands a new critique as well as a new judgement-krinein in Greek-based on new criteria. In my opinion no thinker was more aware of the sheer gravity of our current crisis and the need for an entirely new critique than Bernard. His diagnoses may have often been bleak and dark yet they were also frighteningly accurate as far as I'm concerned and no one probably understood better the magnitude of the challenge that we are confronted with in 'our' time, a time which 'we' have not yet properly managed to make 'ours' - and who that 'we' will be will utterly depend on how it will 'find' itself and responds to its new planetary condition.

The new name of this crisis of planetary proportions that is far more radical than the Axial Age has become the Anthropocene since the turn of the century. When Bernard imported this notion in his thinking in 2014 he characterized it as the Entropocene, as the age of massive and generalized entropization of the biosphere, the most familiar symptoms of which are global warming, loss of biodiversity and ecological destruction. Yet he emphasized that this entropization first of all meant the loss of psychodiversity, sociodiversity and primarily noodiversity, arguing that the ecological crisis had its ultimate roots in a libidinal or indeed noetic crisis - induced by capitalist control and exhaustion of the libidinal economy - and that our response to it should consist in attempting with all our efforts a pharmacological metamorphosis of the global organological arrangement, which he began to call the technosphere in 2018, so as to transform it again into an engine of negentropization, i.e., of the re-emergence and flourishing of diversity at all levels but first of all to reignite desire and forge a new will to know and will to care for the planet. He envisioned this as the birth of what he called the Neganthropocene.

As I said, Bernard in my view was one of the last great maîtres penseurs and visionaries in a time which resentfully rejects such figures, whom Sloterdijk once called 'megalopaths', i.e., those who draw the 'great, unavoidable, insuperable things' - ta megala in Greek-into their 'compassion', as he wrote in 1993 his prescient book Weltfremdheit (Sloterdijk 1993, 380-1), despite the fact that the current age of the Anthropocene is a 
megalopathic crisis of the first order and desperately in need of 'great thinking' and indeed of 'great caring'. Bernard's passing is an incomparable loss to philosophy.

As an adept of the enlightenment, Bernard rejected Heidegger's 'mystagogic' hope for a god who could still save us from our captivity in enframing, yet he was lucid and realistic enough to admit that the bifurcation from the Anthropocene into the Neganthropocene would entail no less than a miracle given the arguably desperate situation in which we find ourselves. Candidly conceding his depression about the state of our world, or rather our 'unworld' [immonde], he wrote in the Age of Disruption: 'I am often overwhelmed because it seems to be absolutely irrational to believe that a positive bifurcation could arise from out of the chaotic period in which we are rushing at the high speeds imposed by disruption. It is totally improbable. And this is a motive for despair' (Stiegler 2019, 303). Yet he summoned us precisely for to believe in that improbability, and that is to say in a miracle. After the death of God and the unlikelihood of a return of the gods we should think of this miracle in terms of negentropy, of the improbability that it represents in the universe, an improbability that nonetheless thrives on this planet, having originated and sustained life and allowing for the utterly improbable lifeform that is Homo sapiens, that 'festival of negentropy' (Sloterdijk 2016, 711), having now become the prime generator of entropy though. If the coming of the neganthropos is the improbable, indeed maybe the impossible, then we should strive - with and in memory of Bernard - for that impossibility and take at heart with Sloterdijk that 'the true realism of the species consists in not expecting less from its intelligence than what is asked of it' (Sloterdijk 1993, 381). For there is indeed, most possibly, no alternative. The ominous year of 2020 may well be called an annus horribilis if not an annus diabolis. Let us nonetheless actively believe that we may once welcome another annus mirabilis in a future that we can still imagine and dream of. And let us therefore hope that Bernard's rich legacy will posthumously be recognized by philosophers of technology and others as the brilliant and original oeuvre that it is, full of potential for future thought, assuming that there will be a future to come.

\section{References}

Lemmens, P. (2011). This system does not produce pleasure anymore. An interview with Bernard Stiegler'. Krisis. Journal for Contemporary Philosophy, 2011(1), 33-41.

Sloterdijk, P. (1993). Weltfremdheit. Frankfurt am Main: Suhrkamp.

Sloterdijk, P. (2013). In the world interior of capital: Towards a philosophical theory of globalization. Cambridge-Malden: Polity.

Sloterdijk, P. (2016). Foams: Spheres III. Cambridge-Malden: Polity.

Sloterdijk, P. (2017). Not saved: Essays after Heidegger. Cambridge-Malden: Polity.

Stiegler, B. (1998). Technics and time 1: The fault of Epimetheus. Stanford: Stanford University Press.

Stiegler, B. (2004). Philosopher par accident. Entrétiens avec Élie During. Paris: Galilée.

Stiegler, B. (2009a). Technics and time 2: Disorientation. Stanford: Stanford University Press.

Stiegler, B. (2009b). Acting out. Stanford: Stanford University Press.

Stiegler, B. (2011). Technics and time 3: Cinematic time and the question of malaise. Stanford: Stanford University Press.

Stiegler, B. (2014). Per toeval filosoferen: Gesprekken met Élie During. Zoetermeer: Klement/Pelckmans.

Stiegler, B. (2016). Dans la disruption. Comment ne pas devenir fou? Paris: Les Liens qui Libèrent.

Stiegler, B. (2017). Philosophising by accident: Interviews with Élie during. Edinburgh: Edinburgh University Press.

Stiegler, B. (2018). The Neganthropocene. London: Open Humanities Press.

Stiegler, B. (2019). The age of disruption: Technology and madness in computational capitalism. Cambridge-Malden: Polity. 
Publisher's Note Springer Nature remains neutral with regard to jurisdictional claims in published maps and institutional affiliations.

Pieter Lemmens teaches philosophy and ethics at the Radboud University in Nijmegen, the Netherlands. He has published on themes in the philosophy of technology, on the work of Martin Heidegger, Peter Sloterdijk and Bernard Stiegler, on post-autonomist Marxism and on themes in philosophical anthropology and (post)phenomenology. Current interests are the political and ecological potentials of new digital media and philosophy of technology in the age of the Anthropocene. His articles have appeared in journals such as Techne, Journal of Agricultural and Environmental Ethics, Philosophy of Technology, Foundations of Science, Human Studies, Angelaki, Krisis and Boundary2. He translated Stiegler's Philosopher par accident in Dutch (2014) and co-edited a book on the philosophy of landscape and place (2011) as well as a volume on contemporary German philosophy (2013), both in Dutch. He currently prepares an introductory book to philosophy of technology in English, to appear mid 2021. 